\title{
Genetic analysis of agronomic and biochemical variables among different tomato (Solanum lycopersicum L.) accessions
}

\author{
Om Prakash Meena ${ }^{1,2^{*}}$,Vijay Bahadur ${ }^{1}$, Ashok Jagtap ${ }^{3}$ and Pawan Saini ${ }^{4}$ \\ ${ }^{1}$ Department of Horticulture, Allahabad School of Agriculture, Sam Higginbottom Institute of Agriculture, \\ Technology and Sciences, Allahabad-211 007 (U.P.), INDIA \\ ${ }^{2}$ Department of Vegetable Science, Punjab Agricultural University, Ludhiana-141 004 (Punjab), INDIA \\ ${ }^{3}$ School of Agricultural Biotechnology, Punjab Agricultural University, Ludhiana-141 004 (Punjab), INDIA \\ ${ }^{4}$ Department of Plant Breeding and Genetics, Punjab Agricultural University, Ludhiana-141 004 (Punjab), INDIA \\ *Corresponding author. E-mail: chandrawatop2@gmail.com
}

Received: March 17, 2015; Revised received: July 20, 2015; Accepted: October 10, 2015

\begin{abstract}
In the present study, thirty accessions of tomato were evaluated for estimation of correlation and path analysis among various quantitative and qualitative characters related to fruit yield. There were highly significant differences among the accessions for all the characters studied as per the analysis of variance. Genotypic correlation coefficients were generally similar in nature and higher in magnitude than the corresponding phenotypic correlation coefficients. The results revealed that the fruit yield plant ${ }^{-1}$ was significantly and positively correlated with number of fruits plant ${ }^{-1}(0.3119$ and 0.3184$)$ followed by fruit set percentage $(0.2434$ and 0.2499$)$, fruit weight (0.6766 and 0.6731$)$, polar diameter of fruit $(0.4687$ and 0.4635$)$ at genotypic and phenotypic level, respectively, indicating that effective improvement in fruit yield plant ${ }^{-1}$ through these characters could be achieved. Fruit weight showed positive and significant genotypic and phenotypic correlation with fruit yield plant ${ }^{-1}$ by having greatest positive direct effect (1.1298 and 1.1116) on fruit yield plant ${ }^{-1}$ at both levels, indicating the true relationship between them and the feasibility to exploit the potentiality of this trait for effective direct selection to improve fruit yield plant ${ }^{-1}$.
\end{abstract}

Keywords: Agronomical, Biochemical variables, Genetic association, Path analysis, Solanum lycopersicum

\section{INTRODUCTION}

Tomato (Solanum lycopersicum L.), a member of the Solanaceae family, is a significant vegetable crop of special economic importance in the horticultural industry worldwide (He et al., 2003; Wang et al., 2005; Liu et al., 2007). It has a chromosome number of $2 \mathrm{n}=24$ (Rick, 1969). Tomato is native of West Coast of South America (Mexico and Peru) and was cultivated by Indians about 500 B.C. long before arrival of Spaniards (Rehman et al., 2000; Tasisa et al., 2012; Meena and Bahadur, 2015a). In India, tomato occupies an area of 0.87 million hectares with a production of 17.50 million tonnes and productivity of 20.11 tonnes per hectare (FAO, 2012). Tomato has been identified as a functional and "nutraceutical" food (Canene-Adams et al., 2005; Adalid et al., 2010). A nutraceutical is any substance considered a food, or part of a food, that provides medical or health benefits, including disease prevention and treatment (Jack, 1995). Tomatoes are a rich source of fibre, vitamins A, C, and lycopene and epidemiological studies indicate that increased consumption of tomato lycopenes is co-incident with a lower occurrence of cardiovascular disease (Arab and Steck, 2000; Sesso et al., 2003) and certain types of cancers (Giovannucci, 2002a,b; Giovannucci et al.,
2002). Recently, the validity of these types of association studies for lowering cancer risks has been questioned (Boffetta et al., 2010), but the evidence supporting the health benefits of tomato consumption remains strong (Willett, 2010). Tomatoes are consumed in many ways, the fresh fruits are eaten in salads, sandwiches and as salsa and the processed varieties are consumed dried or as pastes, preserves, sauces, soups and juices (Chatterjee, 2013). Dishes featuring tomatoes are both traditional and interwoven into the culture of many countries and there are many types of tomatoes with diverse uses which explain its global appeal (Beckles, 2012).

Efforts are being made to increase its productivity by developing superior varieties. However, yield is a complex character, the result of the expression and association of different character, which are highly in-fluenced by the environment (Amorim et al., 2008; Santos et al., 2014a) and its direct improvement is difficult. Knowledge in respect of the nature and magnitude of associations of yield with various component characters is a pre requisite to bring improvement in the desired direction. A crop breeding programme, aimed at increasing the plant productivity requires consideration not only of yield but also of its 
components that have a direct or indirect bearing on yield (Tiwari and Upadhyay, 2011). The development of an effective improvement programme depends upon the existence of genetic variability (Meena and Bahadur, 2013) and knowledge of genotypic and phenotypic correlation of yield components. High genetic variability will increase the chances of establishing superior accessions/genotypes successfully in subsequent generations of selection (Hallauer and Miranda Filho, 1988; Grigolli et al., 2011). Correlation study measures the natural relationship between various traits and helps in determining the component traits on which selection can be based for yield improvement (Cruz and Regazzi, 2006; Grigolli et al., 2011; Izge et al., 2012). In spite of being an easily obtained statistical parameter, care must be taken in interpreting the magnitude of a correla-tion since it is hampered by the direction, by the difference in importance of the character, by the effect of two or more character, and by the effect of environment on expression of the character. In addition, correlation does not allow inferences regarding cause and effect, and so knowledge of the type of association that governs the pair of character is not possible (Furtado et al., 2002). This information, which is indispensable for breeding, can be obtained by means of path analysis. The technique of path coefficient analysis was developed by Wright (1921) and demonstrated by Dewey and Lu (1959) as a means of separating direct and indirect contribution of various traits. It is a standardized partial regression coefficient analysis. It measures the direct influence of one variable upon another and permits the separation of correlation coefficient into components of direct and indirect effects (Hartwig et al., 2007). The use of this technique has been reported to require cause and effect situation among the variables according to Singh and Chaudhary (1977); Silva et al. (2005). Path coefficient analysis is also very useful in formulating breeding strategy to develop elite accessions/genotypes through selection in advanced generations. Thus, the nature and magnitude of variability present in the gene pool for different characters and relationship with each other determine the success of genetic improvement of a character. Since the pattern of inheritance of quantitative characters is highly complex, therefore the present investigation was undertaken to estimate character associations and their direct and indirect effects on yield to facilitate the selection of suitable superior accessions for development of new varieties/ hybrids using standard breeding programme.

\section{MATERIALS AND METHODS}

Experimental site: A field study was carried out during the season 2012-13 at Vegetable Research Farm, Department of Horticulture, Sam Higginbottom Institute of Agriculture, Technology and Sciences, Allahabad, India. The city is situated in south-eastern part of the state Uttar Pradesh, India (25 $28^{\circ} \mathrm{N}$ latitude and $81^{\circ} 54^{\prime} \mathrm{E}$ longitude) and at a mean altitude of $98 \mathrm{~m}$ above sea level. Geologically, the area forms a part of the Indo-Gangetic alluvial plains.

Climate and soil characteristics: The climate of Allahabad is characterized as humid sub-tropical with an average annual rainfall of $1027 \mathrm{~mm}$ (40.4 inches). The rainfall is monsoonal in nature with around $75 \%$ received during July-September. The soil of the experimental field was loamy sand in texture, low in available nitrogen and organic matter, comparatively rich in available phosphorus and medium in available potassium with slightly alkaline reaction. The mean weekly agro-meteorological observations were recorded during the crop season (Fig. 1).

Plant materials: The plant materials comprised of thirty indigenous accessions of determinate tomato collected from Indian Institute of Vegetable Research (IIVR), Varanasi and Vegetable Research Station (VRS), Junagadh Agricultural University, Junagadh, India (Table 1).

Seed sowing, transplanting and cultivation: For raising good and healthy seedlings, the seeds were treated with carbendazim using $2.0 \mathrm{~g}$ per $\mathrm{kg}$ of seed. After that the seeds of thirty accessions of tomato were sown in the nursery bed on 30 September, 2012 and their seedlings were transplanted on $1^{\text {th }}$ November, 2012 in small plots $(2.0 \mathrm{~m} \times 2.40 \mathrm{~m})$ where row-to-row and plant-to-plant spacing was $60 \mathrm{~cm} \times 50 \mathrm{~cm}$ that contained 16 plants. The experiment was laid out in a randomized complete block design (RCBD) with three replications.

Fertilizer application and intercultural operation: All the recommended agronomic package of practices were followed (such as earthing up, irrigation, weeding, fertilization and other cultural practices), as recommended for commercial tomato production. Irrigation water was applied into the plots at 6 to 10 days intervals as required from transplanting to final harvest. Farmyard manure, NPK (given through urea, DAP and muriate of potash, respectively) fertilizer at the rate of 20 tons, $100,70,60 \mathrm{~kg} / \mathrm{ha}$, respectively was applied into the field. One third of $\mathrm{N}$ and the entire dose of farmyard manure, $\mathrm{P}$ and $\mathrm{K}$ was applied at the time of final land preparation while remaining $\mathrm{N}$ was applied at two equal installments, 30 and 50 days after transplanting. Weeding was done as at when required.

Experimental data: The observation were recorded on five randomly selected plants per replication for each accession on fifteen quantitative characters i.e.,

Plant height (cm): The plant height was recorded by measuring the height of randomly selected plants in each plot from the ground level to the main apex; mean values were expressed in $\mathrm{cm}$. The measurement was done at the time of maturity.

Number of branches plant ${ }^{-1}$ : Number of branches plant $^{-1}$ were counted at the maturity stage and means were computed.

Number of leaves plant $^{-1}$ : Counting the number of 
Table 1. Collection of different accessions.

\begin{tabular}{|c|c|c|c|c|c|}
\hline S.N. & Name of Accession & Source & S. N. & Name of Accession & Source \\
\hline 1. & 2011/TODVAR-01 & IIVR, Varanasi & 16. & EC 620533 & IIVR, Varanasi \\
\hline 2. & 2011/TODVAR-03 & IIVR, Varanasi & 17. & EC 620545 & IIVR, Varanasi \\
\hline 3. & 2011/TODVAR-05 & IIVR, Varanasi & 18. & EC 620598 & IIVR, Varanasi \\
\hline 4. & 2011/TODVAR-06 & IIVR, Varanasi & 19. & F 3-1 & IIVR, Varanasi \\
\hline 5. & 2012/TODVAR-01 & IIVR, Varanasi & 20. & 2012/JTL-08-06 & VRS, JAU, Junagadh \\
\hline 6. & 2012/TODVAR-02 & IIVR, Varanasi & 21. & 2012/JTL-08-07 & VRS, JAU, Junagadh \\
\hline 7. & 2012/TODVAR-03 & IIVR, Varanasi & 22. & 2012/JTL-08-14 & VRS, JAU, Junagadh \\
\hline 8. & 2012/TODVAR-04 & IIVR, Varanasi & 23. & 2012/JTL-08-35 & VRS, JAU, Junagadh \\
\hline 9. & 2012/TODVAR-5 & IIVR, Varanasi & 24. & 2012/ATL-01-19 & VRS, JAU, Junagadh \\
\hline 10. & 2012/TODVAR-6 & IIVR, Varanasi & 25. & 2012/ATL-08-21 & VRS, JAU, Junagadh \\
\hline 11. & 2012/TODVAR-7 & IIVR, Varanasi & 26. & 2012/ATL-08-81 & VRS, JAU, Junagadh \\
\hline 12. & 2012/TODVAR-8 & IIVR, Varanasi & 27. & 2012/JT-03 & VRS, JAU, Junagadh \\
\hline 13. & EC 620438 & IIVR, Varanasi & 28. & 2012/AT-03 & VRS, JAU, Junagadh \\
\hline 14. & EC 620452 & IIVR, Varanasi & 29. & Arka Alok & IIVR, Varanasi \\
\hline 15. & EC 620514 & IIVR, Varanasi & 30. & H-86 & IIVR, Varanasi \\
\hline
\end{tabular}

Table 2. Analysis of variance for fifteen characters of tomato accessions.

\begin{tabular}{|c|c|c|c|c|}
\hline \multirow[b]{2}{*}{ S. $\mathbf{N}$. } & \multirow[b]{2}{*}{ Source of Variance/ Characters } & \multicolumn{3}{|c|}{ Mean Sum of Squares } \\
\hline & & $\begin{array}{c}\text { Replication } \\
\text { (d.f.=2) }\end{array}$ & $\begin{array}{c}\text { Treatment } \\
(\text { d.f.=29) }\end{array}$ & $\begin{array}{c}\text { Error } \\
(\text { d.f. }=58)\end{array}$ \\
\hline 1. & Plant Height $(\mathrm{cm})$ & 0.718 & $1666.732 * *$ & 0.559 \\
\hline 2. & Number of branches plant ${ }^{-1}$ & 0.120 & $12.473 * *$ & 0.166 \\
\hline 3. & Number of leaves plant ${ }^{-1}$ & 0.100 & $953.973 * *$ & 0.217 \\
\hline 4. & Days to flowering & 0.165 & $201.589 * *$ & 0.202 \\
\hline 5. & Number of flower clusters plant ${ }^{-1}$ & 0.396 & $11.558 * *$ & 0.316 \\
\hline 6. & Number of flowers plant ${ }^{-1}$ & 0.136 & $270.400 * *$ & 0.343 \\
\hline 7. & Number of fruits plant ${ }^{-1}$ & 0.004 & $92.438 * *$ & 0.447 \\
\hline 8. & Fruit set percentage & 0.144 & $184.286^{* *}$ & 0.836 \\
\hline 9. & Fruit weight $(\mathrm{g})$ & 0.720 & $255.731 * *$ & 0.308 \\
\hline 10. & Radial diameter of fruit ( $\mathrm{mm})$ & 0.205 & $73.411 * *$ & 0.259 \\
\hline 11. & Polar diameter of fruit (mm) & 0.392 & $122.788 * *$ & 0.282 \\
\hline 12. & Fruit yield Plant ${ }^{-1}(\mathrm{~g})$ & 1288.108 & $292275.128 * *$ & 1088.491 \\
\hline 13. & Leaf curl incidence percentage & 0.075 & $459.558 * *$ & 0.083 \\
\hline 14. & $\mathrm{TSS}^{\circ} \mathrm{Brix}$ & 0.014 & $3.371 * *$ & 0.017 \\
\hline 15. & Ascorbic acid (mg/100 g) & 0.112 & $174.688^{* *}$ & 0.131 \\
\hline
\end{tabular}

** Significant at $0.1 \%$

leaves of selected sample plants and the average was recorded.

Days to flowering: To determine days to flowering, the number of days taken from date of transplanting to date of first flower opening were counted on five randomly selected plants and average worked out.

Number of flower clusters plant ${ }^{-1}$ : The numbers of flower clusters were counted from randomly selected plants in each plot and mean was computed.

Number of flowers plant ${ }^{-1}$ : The numbers of flowers were counted from lower, middle and upper clusters of selected plant; average were computed and multiplied with mean of flower clusters plant ${ }^{-1}$.

Number of fruits plant $^{-1}$ : The number of red ripe fruits from each picking were counted, added and divided by five (number of randomly selected plants from which picking was done) to get the average number of fruits plant ${ }^{-1}$.

Fruit set percentage: Data on fruit set percentage was observed by dividing the number of fruits by the number of flowers cluster $^{-1}$ and mean from lower, middle and upper part were calculated.

Fruit weight (g): The weight of 10 randomly taken fruits was measured on the electronic balance and average fruit weight was worked out.

Polar diameter of fruit (mm): Randomly picked sample fruits were used to determine the polar (stem to blossom end) diameter of the fruits with the help of a 'Vernier caliper', values were expressed in $\mathrm{mm}$.

Radial diameter of fruit (mm): The radial diameter of fruits was recorded at the middle portion of the fruit with the help of a 'Vernier caliper' on the same fruit which was used for polar diameter; values were expressed in $\mathrm{mm}$.

Fruit yield plant ${ }^{-1}$ (g): It was calculated by adding the weight of fresh red ripe fruits from each picking and dividing by five (number of randomly selected plants from which picking was done). 
Om Prakash Meena et al. / J. Appl. \& Nat. Sci. 7 (2): 806 - 816 (2015)

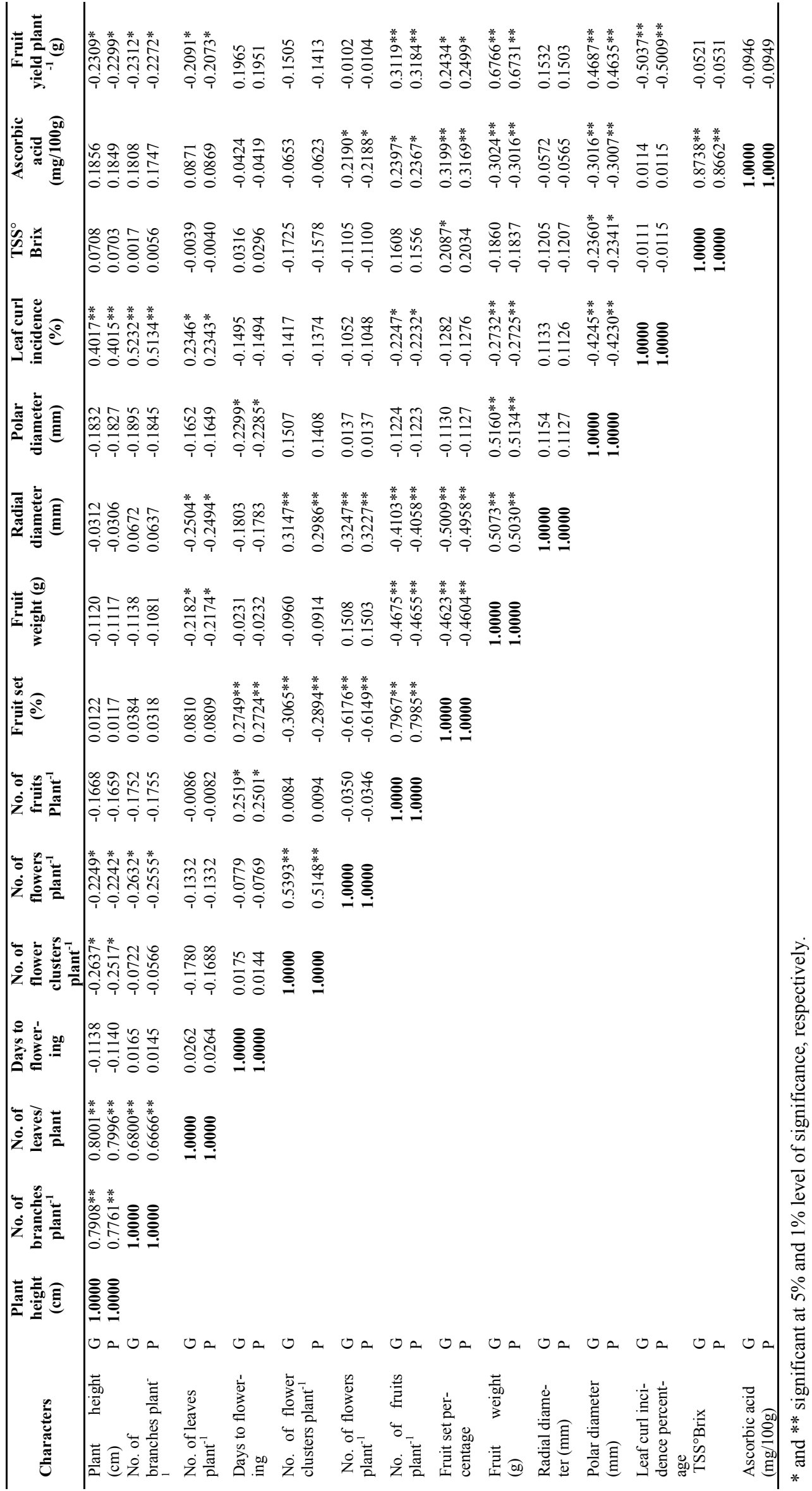




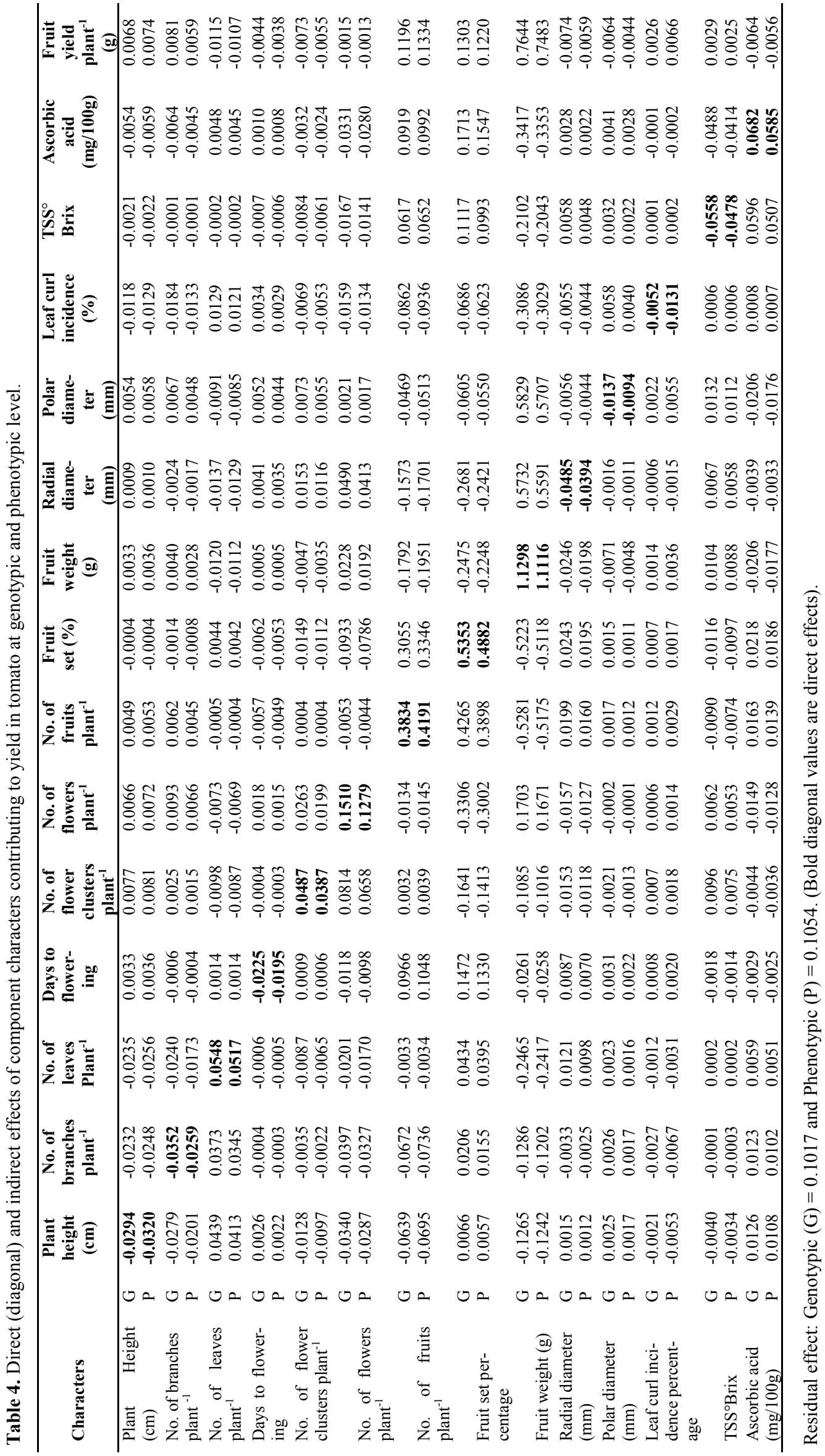


Leaf curl incidence percentage: Based on the scale given by Joshi and Choudhary, 1981.

Total soluble solids ( ${ }^{\circ}$ Brix): Carried out on the selected samples were determined with a hand refractometer (Model: ATAGO, Tokyo, Japan). The refractometer was washed with distilled water each time after use and dried with blotting paper.

Ascorbic acid (mg/100 g): It was estimated using 2,6dichlorophenol indophenol method as illustrated by AOAC (1975).

Statistical analysis: Data of all the previously mentioned characters were arranged and statistically analyzed, using the standard methods of the randomized complete blocks design as illustrated by Clewer and Scarisbrick (2001), using statistical software WINDOSTAT 9.1 developed by INDOSTAT services Ltd. Hyderabad, India.

Analysis of variance: Analysis of variance was done by the method suggested by Panse and Sukhatme (1985).

Estimation of correlations: The correlation coefficient analysis among all possible characters combination at phenotypic (rp) and genotypic (rp) level were estimated employing the formulae

(Al-Jibourie et al., 1958).
Phenotypic correlation $=\mathrm{V}_{\mathrm{xy}(\mathrm{p})}=$

Genotypic correlation $=\mathrm{V}_{\mathrm{xy}(\mathrm{g})}=$

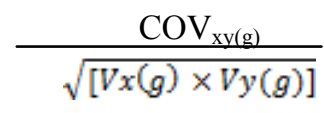

Where:

$\mathrm{COV}_{\mathrm{xy}(\mathrm{p})}=$ Phenotypic co-variance between variables $\mathrm{x}$ and $\mathrm{y}$,

$\mathrm{COV}_{\mathrm{xy}(\mathrm{g})}=$ Genotypic co-variance between variables $\mathrm{x}$ and $\mathrm{y}$,

$\mathrm{V}_{\mathrm{x}(\mathrm{p})}=$ Phenotypic variance for the variable $\mathrm{x}$,

$\mathrm{V}_{\mathrm{x}(\mathrm{g})}=$ Genotypic variance for the variable $\mathrm{x}$,

$V_{y(p)}=$ Phenotypic variance for the variable $y$,

$\mathrm{V}_{\mathrm{y}(\mathrm{g})}=$ Genotypic variance for the variable $\mathrm{y}$.

Significance of correlation coefficient at both phenotypic and genotypic levels was tested by comparing table ' $r$ ' value with obtained value.

Path coefficient analysis: Path coefficient is a standardized partial regression coefficient and as such it is a measure of direct and indirect effect of a set variable (component characters) as a dependent variable such as fruit yield. The estimates of direct and indirect effect of component characters on fruit yield were computed using appropriate correlation coefficient of different component characters as suggested by Wright (1921) and elaborated by Dewey and Lu (1959). Thus, the correlation coefficient of any character with fruit yield was split into direct and indirect effects adopting the standard formula.

$r_{i y}=r_{1 i} P_{1}+r_{2 i} P_{2}+r_{3 i} P_{3}+\ldots+r_{n i} P_{n}+\ldots r_{i i} P_{1}$

Where:

$\mathrm{r}_{\mathrm{iy}}=$ Correlation of the ith character with fruit yield, $r_{n i}=$ Correlation between nth character with ith character,

$\mathrm{n}=$ Number of independent variables (component characters),

$\mathrm{P}_{\mathrm{i}}=$ Direct effect of ith character on fruit yield.

Direct effects of different component character on fruit yield were obtained by solving the following equations.

$\mathrm{r}_{\mathrm{iy}}=\left[\mathrm{P}_{\mathrm{I}}\right]\left[\mathrm{r}_{\mathrm{ij}}\right]$ which can also be rearranged as $\left[\mathrm{P}_{\mathrm{I}}\right]=$ $\left[\mathrm{r}_{\mathrm{iy}}\right]^{-1}\left[\mathrm{r}_{\mathrm{ij}}\right]$

Where:

$\left[\mathrm{P}_{\mathrm{I}}\right]=$ Matrix of direct effect,

$\left[\mathrm{r}_{\mathrm{ij}}\right]=$ Matrix of correlation coefficients among all the $\mathrm{n}$ components characters,

$\left[\mathrm{r}_{\mathrm{iy}}\right]=$ Matrix of correlation of all component characters with fruit yield,

$\mathrm{r}_{\mathrm{il}}=$ Indirect effect of $\mathrm{i}^{\text {th }}$ character on fruit yield through first characters.

The residual effect was obtained by the following formula.

Residual effect $=\mathrm{PR}=\sqrt{1} \quad-P_{\mathrm{i}} \mathrm{r}_{\mathrm{iy}}$

Where: $P_{i}$ and $r_{i y}$ are as given above.

\section{RESULTS AND DISCUSSION}

Analysis of variance: The analysis of variance revealed significant differences among accessions for all the traits studies (Table 2). The highly significant differences among the accessions for all the traits indicate sufficient diversity among them which can be exploited through selection. Significant differences among the accessions for all the studied traits were also noticed by Barman et al. (1995); Singh and Raj (2004); Singh and Cheema (2005); Hidayatullah et al. (2008); Basavaraj et al. (2010); Dar and Sharma (2011); Kaushik et al. (2011); Porta et al. (2014); Santos et al. (2014b). In a breeding program, quantification of genetic variability of a population is a determining factor since it reveals the genetic structure of the populations (Santos et al., 2014a).

Correlation coefficient analysis: Yield of a crop is the result of interaction of a number of inter-related characters. Therefore, selection should be based on these component characters after assessing their correlation with yield. Character association revealed the mutual relationship between two characters, and it is important parameters for taking a decision regarding the nature of selection to be followed for improvement in the crop under study. The phenotypic and genotypic correlation among the yield and yield components in tomato are presented in Table 3 and Fig. 2. Significant correlation of characters suggested that there is much scope for direct and indirect selection for further improvement. Genotypic correlation coefficient provides measures of genetic association between traits and thus helps to identify the more important as well as less important traits to be considered in breeding programmes (Tiwari and Upadhyay, 2011). In general, 


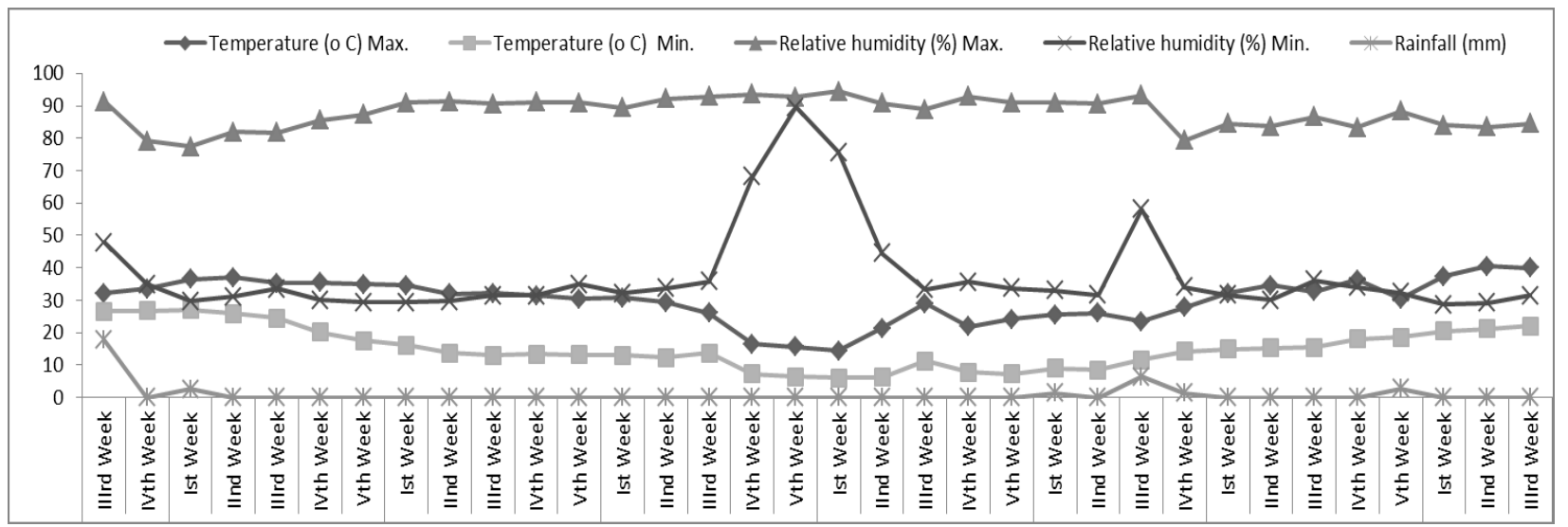

Fig. 1. Mean weekly agro-meteorological observations recorded during crop season 2012-13.

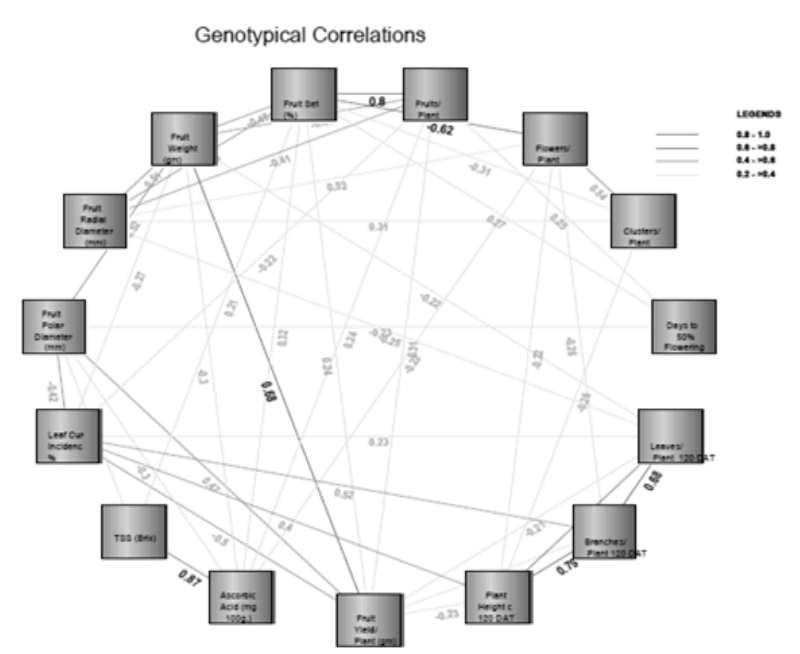

Fig. 2. Genotypic correlation among various traits of tomato.

the coefficients of genetic correlation for all traits were higher than their corresponding coefficients of phenotypic correlation, thereby, suggesting strong inherent association among the characters studies. The low phenotypic value might be due to appreciable interaction of the accessions/genotypes with the environment. The higher genotypic correlation than phenotypic correlation have also been reported by Harer et al. (2002); Kumar et al. (2003); Golani et al. (2007); Dar et al. (2011); Tasisa et al. (2012); Srivastava et al. (2013); Santos et al. (2014a). The nature of genotypic correlation was similar to phenotypic correlation. However, in some cases correlation coefficients at genotypic level were significant, while at phenotypic level same were found to be non-significant (Kumari and Sharma, 2013).

In Solanaceaous crop plants, number of fruits and fruit weight are usually associated with higher yield. Our data also indicated significant positive genetic and phenotypic correlations between fruit yield plant ${ }^{-1}$ and number of fruits plant ${ }^{-1}(\mathrm{r}=0.3119$ and 0.3184$)$, fruit set percentage $(\mathrm{r}=0.2434$ and 0.2499$)$, fruit weight $(r=0.6766$ and 0.6731$)$, polar diameter of fruit $(\mathrm{r}=0.4687$ and 0.4635$)$, indicating that effective improvement in fruit yield plant $^{-1}$ through these

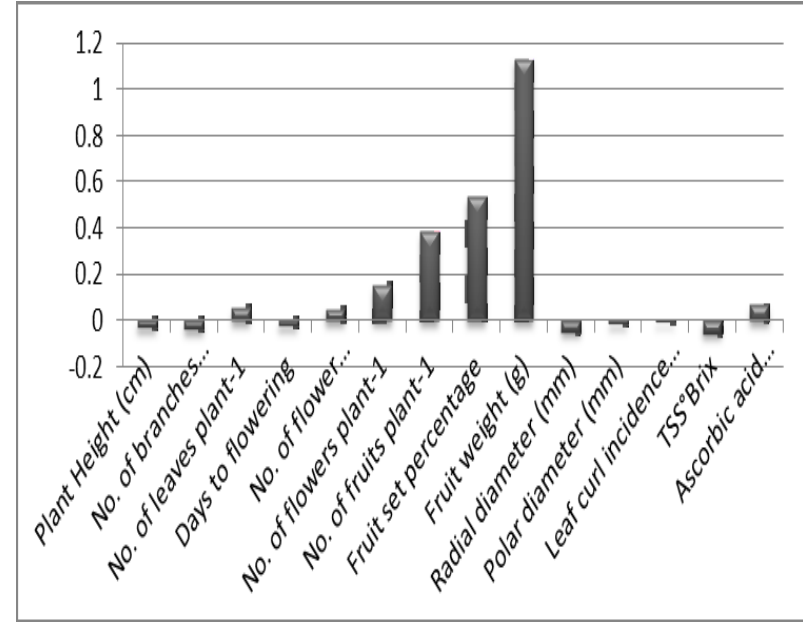

Fig. 3. Direct (Path coefficient analysis) effect of quantitative and qualitative traits on fruit yield plant ${ }^{-1}$ at genotypic level.

characters could be achieved. Similar results have also been reported by Kumar et al. (2003), Dhankhar and Dhankar (2006), Kumar et al. (2006), Tasisa et al. (2012), Reddy et al. (2013) for number of fruits plant $^{-1}$; Singh et al. (2004) for number of fruits plant ${ }^{-1}$, fruit weight and fruit diameter; Ara et al. (2009), Kumar and Dudi (2011) for average fruit weight and number of fruits plant ${ }^{-1}$; Rani et al. (2010), Sharma and Singh (2012) for fruit weight.

Plant height showed significant and positive association with number of branches plant ${ }^{-1}$, number of leaves plant $^{-1}$ and leaf curl incidence percentage at genotypic and phenotypic level. This is in agree-ment with the results found by Ogwulumba and Ugwuoke (2013) for number of leaves plant ${ }^{-1}$; Meena and Bahadur (2015b) for number of branches plant ${ }^{-1}$ and number of leaves plant $^{-1}$. On the other hand days to flowering showed significant and positive association with number of fruits plant $^{-1}$ and fruit set percentage at genotypic and phenotypic level. The results indicated that early flowering increase the number of fruits plant $^{-1}$ and fruit set percentage.

The trait, number of fruits plant ${ }^{-1}$ showed significant and positive association with days to flowering, fruit set percentage, ascorbic acid and fruit yield plant ${ }^{-1}$ at 
genotypic and phenotypic level, indicating that fruit yield may be obtained in an indirect manner with selection for increase in the number of fruits per plant. Similar types of findings were also reported by Das et al. (1998), Haydar et al. (2007), Hidayatullah et al. (2008), Islam et al. (2010), Dar et al. (2011) for fruit yield plant ${ }^{-1}$, Meena and Bahadur (2015b) for fruit set percentage and fruit yield plant $^{-1}$. Its association with the character like fruit weight, radial diameter of fruit and leaf curl incidence was negative and significant which indicated that as the number of fruits increases, the individual fruit weight and radial diameter would decreases. Similar type of association was reported by Islam et al. (2010) for fruit weight and radial diameter of fruit; Srivastava et al. (2013) for fruit weight. In the present investigation, positive association of the fruit weight with radial diameter of fruit, polar diameter of fruit and fruit yield plant ${ }^{-1}$ was observed at both levels, which indicated that as the fruit weight increases the fruit yield plant ${ }^{-1}$ and those traits would also increase (Singh et al., 2004; Rani et al., 2010). Whereas, fruit weight was negative correlated with number of leaves plant $^{-1}$, number of fruits plant ${ }^{-1}$, fruit set percentage, leaf curl incidence percentage and ascorbic acid indicated that as the fruit weight increases, those traits would decrease. These results are in confirmation with the findings of Srivastava et al. (2013) for number of fruits plant ${ }^{-1}$.

Polar diameter of fruit showed positive significant correlation both at genotypic and phenotypic level with fruit weight and fruit yield plant ${ }^{-1}$ which indicated that as the polar diameter of fruits increases; the fruit weight and yield plant $^{-1}$ would also increase. Prasad and Rai (1999), Agong et al. (2008), Islam et al. (2010) reported very high and significant correlation coefficient for fruit yield and fruit weight. TSS showed non-significant and negative correlation with number of leaves plant ${ }^{-1}$, number of flower clusters plant ${ }^{-1}$, number of flowers plant ${ }^{-1}$, fruit weight, radial diameter of fruits, leaf curl incidence percentage and fruit yield. It has also been reported that a non-significant association of TSS with yield plant ${ }^{-1}$ and fruit weight (Nirmaladevi and Tikoo, 1992; Premalakshmi, 2001). In the present investigation the absence of significant association was not only with yield but also with fruit weight and other traits were seen. This would help the breeder to develop good $\mathrm{F}_{1}$ hybrids with better yield as well as TSS. The TSS had strong positive and significant inter association with ascorbic acid, which was also earlier reported (Aruna, 1992; Jawaharlal, 1994; Indu Nair, 1995). Ascorbic acid (mg/100 g) showed significant and positive association with number of fruits plant ${ }^{-1}$, fruit set percentage and TSS at genotypic and phenotypic level. The result was in full agreement with earlier studies by Meena and Bahadur (2015b) for TSS.

Path coefficient analysis: Yield is the sum total of the several component characters which directly or indirectly contributed to it. Correlation studies give an idea about the positive and negative associations of different characters with yield and also among themselves. However, the nature and extent of contribution of these characters towards yield is not obtained. Hence, path coefficient analysis was used to make partition of the correlation coefficient of the different characters studied to know direct and indirect effects on yield. The information obtained helps in giving proper weightage to the various characters during selection or other breeding programme so that the improvement of desirable traits can be achieved effectively (Bhatt, 1973; Meena and Bahadur, 2015b). The results of the present investigation on path coefficient analysis as presented in Table 4 revealed that fruit weight had a very high positive direct genotypic and phenotypic effect 1.1298 and 1.1116 , respectively on fruit yield plant $^{-1}$ (Fig. 3) followed by fruit set percentage $(0.5353$ and 0.4882$)$, number of fruits plant $^{-1}(0.3834$ and 0.4191$)$, number of flowers plant ${ }^{-1}$ $(0.1510$ and 0.1279$)$, ascorbic acid $(0.0682$ and $0.0585)$, number of leaves plant ${ }^{-1}(0.0548$ and 0.0517$)$ and number of clusters plant ${ }^{-1}(0.0487$ and 0.0387$)$. The results in accordance with the finding of Dudi and Kalloo (1982), Verma and Sarnaik (2000), Ara et al. (2009), Kumar and Dudi (2011), Sharma and Singh (2012) for fruit weight and number of fruits plant ${ }^{-1}$; Golani et al. (2007) for fruit weight; Manna and Paul (2012) for number of fruits plant ${ }^{-1}$, fruit weight and ascorbic acid; Reddy et al. (2013) for number of fruits plant $^{-1}$ and ascorbic acid. On the other hand the traits, viz., plant height, number of branches plant ${ }^{-1}$, days to flowering, radial diameter of fruit, polar diameter of fruit, leaf curl incidence percentage and TSS had negative direct effect toward yield at the genotypic as well as phenotypic level. Similar results have also been reported by Singh et al. (2004) for plant height and TSS; Asati et al. (2008) for number of primary branches plant ${ }^{-1}$ and days to flowering; Dar et al. (2011) for TSS; Tiwari and Upadhyay (2011) for plant height; Reddy et al. (2013) for days to flowering and number of primary branches plant ${ }^{-1}$.

Plant height exhibited positive indirect effect on fruit yield via days to flowering, number of flower clusters plant $^{-1}$, number of flowers plant ${ }^{-1}$, number of fruits plant $^{-1}$, fruit weight, radial diameter of fruit and polar diameter of fruits. Similar results have also been reported by Tiwari and Upadhyay (2011) for days to flowering and fruit weight. Days to flowering exhibited positive indirect effect on fruit yield via plant height, number of flowers plant ${ }^{-1}$, fruit weight, radial diameter of fruit, polar diameter of fruit, leaf curl incidence percentage and ascorbic acid. Similar results have also been reported by Tiwari and Upadhyay (2011) for fruit weight. TSS ${ }^{\circ}$ Brix exhibited positive indirect effect on fruit yield via number of leaves plant $^{-1}$, number of flower clusters plant ${ }^{-1}$, number of flowers plant ${ }^{-1}$, fruit weight, radial diameter of fruit, 
polar diameter of fruit and leaf curl incidence percentage.

\section{Conclusion}

In present investigation, fruit weight showed high positive and direct effect had significant positive correlation with fruit yield plant ${ }^{-1}$. Therefore, the fruits with higher weight should be considered in selection criteria for increasing fruit yield plant ${ }^{-1}$. The present study suggested that more emphasis should be given to selecting accessions with high fruit weight. Directly or indirectly all characters showed positive effect on fruit yield plant ${ }^{-1}$. The residual effect of the genotypic and phenotypic path analysis was very less i.e. 0.1017 and 0.1054 , respectively. This indicates that the characters chosen for the present study is the main components of yield and that the variability in yield is accounted by the characters chosen for this investigation to a considerable extent. Correlation and path coefficient studies suggested that the selection should be primarily based on the component characters which exhibited significant positive correlation with yield and also had either direct or indirect effect on yield. This may lead to development of high yielding accessions in tomato.

\section{ACKNOWLEDGEMENTS}

We express our gratitude to Indian Institute of Vegetable Research, Varanasi, U.P. and Vegetable Research Station, Junagadh Agricultural University, Junagadh, Gujarat (India) for providing accessions of tomato for this research.

\section{REFERENCES}

Adalid, A.M., Rosello, S. and Nuez, F. (2010). Evaluation and selection of tomato accessions (Solanum section Lycopersicon) for content of lycopene, b-carotene and ascorbic acid. Journal of Food Composition and Analysis, 23: 613-618.

Agong, S.G., Schittenhelm, S. and Friedt, W. (2008). Genotypic variation of Kenyan tomato (Lycopersicon esculentum L.) germplasm. PGR Newsletter, FAO Biodiversity, 123: 61-67.

Al-Jibourie, H.A., Miller, P.A. and Robinson, H.F. (1958). Genotypic and environmental variance in an upland cotton cross of interspecific origin. Agronomy Journal, 50: 663-637.

Amorim, E.P., Ramos, N.P., Ungaro, M.R.G. and Kiihl, T.A.M. (2008). Correlações e análise de trilha em girassol. Bragantia, 67: 307-316.

AOAC (1975). In: Horowitz W (ed), Official Methods of Analysis. Association of Official Analytical Chemists, Washington, DC, USA.

Ara, A., Narayan, R., Ahmed, N. and Khan, S.H. (2009). Genetic variability and selection parameters for yield and quality attributes in tomato. Indian Journal of Horticulture, 66 (1): 73-78.

Arab, L. and Steck, S. (2000). Lycopene and cardiovascular disease. American Journal of Clinical Nutrition, 71: 1691-1695.

Aruna, S. (1992). Studies on the performance of certain $F_{1}$ hybrids in tomato (Lycopersicon esculentum Mill.). M.Sc. Thesis. Tamil Nadu Agricultural University. Coimbatore.

Asati, B.S., Rai, N. and Singh, A.K. (2008). Genetic parameters study for yield and quality traits in tomato. The Asian Journal of Horticulture, 3(2): 222-225.

Barman, D., Sharma, C.K., Singh, I.P. and Sardana, S.D.L.C. (1995). Genetic variability in exotic lines of tomato (Lycopersicon esculentum Mill.) in off season. International Journal of Tropical Agriculture, 13: 265-268.

Basavaraj, S.N., Hosamani, R.M. and Patil, B.C. (2010). Genetic variability in tomato (Solanum lycopersicon [Mill] Wattsd.). Karnataka Journal of Agricultural Sciences, 23(3): 536-537.

Beckles, D.M. (2012). Factors affecting the postharvest soluble solids and sugar content of tomato (Solanum lycopersicum L.) fruit. Postharvest Biology and Technology, 63: 129-140.

Bhatt, G.H. (1973). Significance of path coefficient analysis in determining the nature of character association. Euphytica, 22: 338-343.

Boffetta, P., Couto, E., Wichmann, J., Ferrari, P., Trichopoulos, D., Bueno-de-Mesquita, H.B.,....Trichopoulou, A. (2010). Fruit and vegetable intake and overall cancer risk in the European Prospective Investigation into Cancer and Nutrition (EPIC). Journal of the National Cancer Institute, 102: 529-537.

Canene-Adams, K., Campbell, J.K., Zaripheh, S., Jeffery, E.H. and Erdman, J.W. (2005). The tomato as a functional food. Journal of Nutrition, 135: 1226-1230.

Chatterjee, R. (2013). Physiological attributes of tomato (Lycopersicon esculentum Mill.) influenced by different sources of nutrients at foothill of eastern Himalayan region. Journal of Applied and Natural Science, 5(2): 282-287.

Clewer, A.G. and Scarisbrick, D.H. (2001). Practical statistics and experimental design for plant and crop science. John Wiley \& Sons Ltd., New York, p. 346.

Cruz, C.D. and Regazzi, A.J. (2006). Modelos biométricos aplicados ao melhoramento genético. UFV, Viçosa, $585 \mathrm{p}$.

Dar, R.A. and Sharma, J.P. (2011). Genetic variability studies of yield and quality traits in tomato (Lycopersicon esculentum Mill). International Journal of Plant Breeding and Genetics, 5 (2): 168-174.

Dar, R.A., Sharma, J.P., Gupta, R.K. and Chopra, S. (2011). Studies on correlation and path analysis for yield and physico chemical traits in tomato (Lycopersicon esculentum Mill). Vegetos, 24 (2): 136-141.

Das, B., Hazarika, M.H. and Das, P.K. (1998). Genetic variability and correlation in fruit characters of tomato (Lycopersicon esculentum Mill.). Annals of Agricultural Research, 19 (1): 77-80.

Dewey, D.R. and Lu, K.H. (1959). A correlation and path analysis of the components of crested wheat grass seed production. Agronomy Journal, 51: 515-518.

Dhankhar, S.K. and Dhankar, S.S. (2006). Variability, heritability, correlation and path coefficient studies in tomato. Haryana Journal of Horticultural Sciences, 35(1\&2): 179-181.

Dudi, B.S. and Kalloo, G. (1982). Correlation and path analysis studies in tomato. Haryana Journal of Horticultural Sciences, 11: 122-126.

FAO (2012). Food and Agriculture Organization of the United Nations. www.faostat.fao.org. 
Furtado, M.R., Cruz, C.D., Cardoso, A.A., Coelho, A.D.F. and Peternelli, L.A. (2002). Análise de trilha do rendimento do feijoeiro e seus componentes primários em monocultivo e em consórcio com a cultura do milho. Ciência Rural, 32: 217-220.

Giovannucci, E. (2002a). Lycopene and prostate cancer risk. Methodological considerations in the epidemiologic literature. Pure and Applied Chemistry, 74: 1427-1434.

Giovannucci, E. (2002b). A review of epidemiologic studies of tomatoes, lycopene, and prostate cancer. Experimental Biology and Medicine, 227: 852-859.

Giovannucci, E., Rimm, E.B., Liu, Y., Stampfer, M.J. and Willett, W.C. (2002). A prospective study of tomato products, lycopene, and prostate cancer risk. Journal of the National Cancer Institute, 94: 391-398.

Golani, I.J., Mehta, D.R., Purohit, V.L., Pandya, H.M. and Kanzariya, M.V. (2007). Genetic variability, correlation and path coefficient studies in tomato. Indian Journal of Agricultural Research, 41(2): 146-149.

Grigolli, J.F.J., Kubota, M.M., Alves, D.P., Rodrigues, G.B., Cardoso, C.R., Silva, D.J.H. and Mizubuti, E.S.G. (2011). Characterization of tomato accessions for resistance to early blight. Crop Breeding and Applied Biotechnology, 11: 174-180.

Hallauer, A.R. and Miranda Filho, J.B. (1988). Quantitative genetics in maize breeding. Iowa State University Press, Ames, $468 \mathrm{p}$

Harer, P.N., Lad, D.B. and Bhor, T.J. (2002). Correlation and path analysis studies in tomato. Journal of Maharashtra Agricultural Universities, 27(3): 302-303.

Hartwig, I., Carvalho, F.I.F., Oliveira, A.C., Silva, J.A.G., Lorencetti, C., Benin, G., Vieira, E.A., Bertan, I., Silva, G.O., Valério, I.P., André, D. and Schmidt, M. (2007). Estimativa de coeficientes de correlação e trilha em gerações segregantes de trigo hexaplóide. Bragantia, 66: 203-218.

Haydar, A., Mandal, M.A., Ahmed, M.B., Hannan, M.M., Karim, R., Razvy, M.A., Roy, U.K. and Salahin, M. (2007). Studies on genetic variability and interrelationship among the different traits in tomato (L. esculentum Mill.). Middle-East Journal of Scientific Research, 2(3-4): 139-142.

He, C., Poysa, V. and Yu, K. (2003). Development and characterization of simple sequence repeat (SSR) markers and their use in determining relationship among $L y$ copersicon esculentum cultivars. Theoretical and Applied Genetics, 106: 363-373.

Hidayatullah, Jatoi, S.A., Ghafoor, A. and Mahmood, T. (2008). Path coefficient analysis of yield component in tomato (Lycopersicon esculentum). Pakistan Journal of Botany, 40(2): 627-635.

Indu Nair, P. (1995). Genetic variability in certain exotic collection of tomato (Lycopersicon esculentum Mill.). M.Sc. Thesis, Tamil Nadu Agricultural University, Coimbatore.

Islam, B.M.R., Ivy, N.A., Rasul, M.G. and Zakaria, M. (2010). Character association and path analysis of exotic tomato (Solanum lycopersicum L.) genotypes. Bangladesh Journal of Plant Breeding and Genetics, 23 (1): 13-18.

Izge, A.U., Garba, Y.M. and Sodangi, I.A. (2012). Correlation and path coefficient analysis of tomato (Lycopersicon lycopersicum L. Karst) under fruit worm (Heliothis Zea Buddie) infestation in a line $\times$ tester. Journal of Environmental Issues and Agriculture in
Developing Countries, 4(1): 24-30.

Jack, D.B. (1995). Keep taking the tomatoes-the exciting world of nutraceuticals. Molecular Medicine Today, 1: 118-121.

Jawaharlal, M. (1994). Genetic studies for fruit yield and quality characteristics in tomato (Lycopersicon esculentum Mill.). Ph.D. Thesis, Tamil Nadu Agricultural University, Coimbatore.

Joshi, G.C. and Choudhury, B. (1981). Screening of Lycopersicon and Solanum species for resistance to leaf curl virus. Vegetable Science, 8: 45-50.

Kaushik, S.K., Tomar, D.S. and Dixit, A.K. (2011). Genetics of fruit yield and it's contributing characters in tomato (Solanum lycopersicum). Journal of Agricultural Biotechnology and Sustainable Development, 3(10): 209-213.

Kumar, M. and Dudi, B.S. (2011). Study of correlation for yield and quality characters in tomato (Lycopersicon esculentum Mill.). Electronic Journal of Plant Breeding, 2(3): 453-460

Kumar, R., Kumar, N., Singh, J. and Rai, G.K. (2006). Studies on yield and quality traits in tomato. Vegetable Science, 33(2): 126-132.

Kumar, V.R.A., Thakur, M.C. and Hedau, N.K. (2003). Correlation and path coefficient analysis in tomato (Lycopersicon esculentum Mill.). Annals of Agricultural Research, 24(1): 175-177.

Kumari, S. and Sharma, M.K. (2013). Genetic variability studies in tomato (Solanum lycopersicum L.). Vegetable Science, 40(1): 83-86.

Liu, L.W., Wang, Y., Gong, Y.Q., Zhao, T.M., Liu, G., Li, X.Y. and Yu, F.M. (2007). Assessment of genetic purity of tomato (Lycopersicon esculentum L.) hybrid using molecular markers. Scientia Horticulturae, 115: 7-12.

Manna, M. and Paul, A. (2012). Studies on genetic variability and character association of fruit quality parameters in tomato. HortFlora Research Spectrum, 1(2): 110-116.

Meena, O.P. and Bahadur, V. (2013). Assessment of breeding potential of tomato (Lycopersicon esculentum Mill.) germplasm using $\mathrm{D}^{2}$ analysis. The Bioscan, 8(4): 1145 1148 .

Meena, O.P. and Bahadur, V. (2015a). Breeding potential of indeterminate tomato (Solanum lycopersicum L.) accessions using $\mathrm{D}^{2}$ analysis. SABRAO Journal of Breeding and Genetics, 47(1): 49-59.

Meena, O.P. and Bahadur, V. (2015b). Genetic associations analysis for fruit yield and its contributing traits of indeterminate tomato (Solanum lycopersicum L.) germplasm under open field condition. Journal of Agricultural Science, 7(3): 148-163.

Nirmaladevi, S. and Tikoo, S.K. (1992). Studies of the reaction of certain tomato genotypes and their $F_{1}$ to combined infection by Meloidogyne incognita and Pseudomnas solanaceaum. Indian Journal of Genetics and Plant Breeding, 52: 118-125.

Ogwulumba, S.I. and Ugwuoke, K.I. (2013). Coefficient and path analyses of the impact of root galls caused by Meloidogyne javanica on some growth and yield parameters of tomato (Solanum lycopersicum). International Journal of Plant and Soil Science, 2(2): 222-229.

Panse, V.G. and Sukhatme, P.V. (1985). Statistical Methods for Agricultural Workers ( $2^{\text {nd }}$ ed), Indian Council of Agricultural Research, New Delhi. 381p. 
Porta, B., Rivas, M., Gutiérrez, L. and Galván, G.A. (2014). Variability, heritability, and correlations of agronomic traits in an onion landrace and derived $\mathrm{S}_{1}$ lines. Crop Breeding and Applied Biotechnology, 14: 29-35.

Prasad, V.S.R.K. and Rai, M. (1999). Genetic variation, component association and direct and indirect selections in some exotic tomato germplasm. Indian Journal of Horticulture, 56(3): 262-266.

Premalakshmi, V. (2001). Breeding for yield and post harvest qualities in tomato (Lycopersicon esculentum Mill.). Ph.D. Thesis, Tamil Nadu Agricultural University, Coimbatore.

Rani, C.I., Muthuvel, I. and Veeraragavathatham, D. (2010). Correlation and path analysis of yield components and quality traits in tomato (Lycopersicon esculentum Mill.). Agricultural Science Digest, 30(1): 11-14.

Reddy, B.R., Reddy, M.P., Reddy, D.S. and Begum, H. (2013). Correlation and path analysis studies for yield and quality traits in tomato (Solanum lycopersicum L.). IOSR Journal of Agriculture and Veterinary Science (IOSR-JAVS), 4(4): 56-59.

Rehman, F., Khan, S., Aridullah, F. and Shafiullah. (2000). Performance of different tomato cultivars under the climatic condition of northern areas (GILGIT). Pakistan Journal of Biological Sciences, 3: 833-835.

Rick, C.M. (1969). Origin of cultivated tomato, current status of the problem. Abstract XI International Botanical Congress, Seattle, Washington held on August 4 September 2, 1969. $180 \mathrm{p}$.

Santos, A., Ceccon, G., Davide, L.M.C., Correa, A.M. and Alves, V.B. (2014a). Correlations and path analysis of yield components in cowpea. Crop Breeding and Applied Biotechnology, 14: 82-87.

Santos, P.H.A.D., Pereira, M.G., Trindade, R.S., Cunha, K.S., Entringer, G.C. and Vettorazzi, J.C.F. (2014b). Agronomic performance of super-sweet corn genotypes in the north of Rio de Janeiro. Crop Breeding and Applied Biotechnology, 14: 8-14.

Sesso, H.D., Liu, S.M., Gaziano, J.M. and Buring, J.E. (2003). Dietary lycopene, tomato-based food products and cardiovascular disease in women. Journal of Nutrition, 133: 2336-2341.

Sharma, B. and Singh, J.P. (2012). Correlation and path coefficient analysis for quantitative and qualitative traits for fruit yield and seed yield in tomato genotypes. Indian Journal of Horticulture, 69(4): 540-544.

Silva, S.A., Carvalho, F.I.F., Nedel, J.L., Cruz, P.J., Silva, J.A.G., Caetano, V.R., Hartwig, I. and Sousa, C.S. (2005). Análise de trilha para os componentes de rendimento de grãos em trigo. Bragantia, 64: 191-196.

Singh, A.K. and Raj, N. (2004). Variability studies in tomato under cold arid condition of Ladakh. Horticulture Journal, 17: 67-72.

Singh, H. and Cheema, D.S. (2005). Studies on genetic variability and heritability for quality traits of tomato (Lycopersicon esculentum Mill.) under heat stress conditions. Journal of Applied Horticulture, 7(1):55-57.

Singh, J.K., Singh, J.P., Jain, S.K. and Joshi, A. (2004). Correlation and path coefficient analysis in tomato. Progressive Horticulture, 36(1): 82-86.

Singh, R.K. and Chaudhary, B.D. (1977). Biometrical Methods in Quantitative Genetic Analysis. New Delhi: Kalyani Publishers.

Srivastava, K., Kumari, K., Singh, S.P. and Kumar, R. (2013). Association studies for yield and its component traits in tomato (Solanum lycopersicum L.). Plant Archives, 13(1): 105 -112 .

Tasisa, J., Belew, D. and Bantte, K. (2012). Genetic association analysis among some traits of tomato (Lycopersicon esculentum Mill.) genotypes in West Showa, Ethiopia. International Journal of Plant Breeding and Genetics, 6(3): 129-139.

Tiwari, J.K. and Upadhyay, D. (2011). Correlation and path coefficient studies in tomato (Lycopersicon esculentum Mill.). Research Journal of Agricultural Sciences, 2(1): 63-68

Verma, S.K. and Sarnaik, D.A. (2000). Path analysis of yield components in tomato (Lycopersicon esculentum Mill.). Journal of Applied Biology, 10(2): 136-138.

Wang, X.F., Knoblauch, R. and Leist, N. (2005). Varietal discrimination of tomato (Lycopersicon esculentum L.) by ultrathin-layer isoelectric focusing of seed protein. Seed Science and Technology, 28: 521-526.

Willett, W.C. (2010). Fruits, vegetables, and cancer prevention: turmoil in the produce section. Journal of the National Cancer Institute, 102: 510-511.

Wright, S. (1921). Correlation and causation. Journal of Agricultural Research, 20: 557-587. 